\title{
İÇ KONTROLDE COSO ve ICFR İLIŞKİSi
}

\author{
THE RELATIONSHIP BETWEEN COSO AND ICFR IN INTERNAL CONTROL
}

\begin{abstract}
Mehtap KARAKOÇ
Serkan ÖZDEMİR ${ }^{2}$

$\ddot{O} z$

Bu çalışmada iç kontrol modellerinden COSO tüm boyutlarıyla açıklanmış, Sarbanes Oxley Kanunu (SOA) ile Amerikan Sermaye Piyasası'nın (SEC) şirketlerinden düzenli olarak istediği Finansal Raporlama ile İlgili İç Kontrol Raporu (Internal Control over Financial Reporting-ICFR) arasındaki ilişki üzerinde durulmuştur.

Bu bağlamda COSO'nun 1985 yılından itibaren yaşadığı gelişmeler hakkında bilgi verilmiştir. COSO'nun iç kontrole katkıları ve aldığı yollar incelenmiştir. COSO'nun yayınladığı çerçeveler göz önüne alınarak COSO Kübü ve temel prensipler üzerinde durulmuştur. SOA'un yürürlüğe girmesinden sonra SEC'in şirketlerinden zorunlu olarak istediği ICFR hakkında ayrıntılı bilgi verilmiştir.
\end{abstract}

Anahtar Kelimeler: Denetim, İç Kontrol, COSO, COSO Kübü, Finansal Raporlama ile İlgili İç Kontrol Raporu

\begin{abstract}
In this study, COSO which is one of the internal control models was explained thoroughly and the relationship between COSO and Internal Control over Financial Reporting (ICFR), which American Capital Market (SEC) asked from companies regularly through Sarbanes Oxley Act (SOA), was mentioned.

Within this scope, information about the development that COSO has gone through since 1985 was provided. The contributions of COSO to internal control and the emerging developments were investigated. Taking the frameworks issued by COSO into account, COSO Cube and COSO's basic principles were focused on. Detailed information about ICFR, which SEC asked from listed companies after Sarbanes Oxley Act came into operation, was provided.
\end{abstract}

Keywords: Audit, Internal control, COSO, COSO cube, Internal Control over Financial Reporting

\footnotetext{
${ }^{1}$ Yrd.Doç.Dr., Uşak Üniversitesi, Uygulamalı Bilimler Yüksekokulu, Muhasebe Bilgi Sistemleri Bölümü, erdemmehtap@hotmail.com

$\frac{2}{2}$ Yrd.Doç.Dr., Pamukkale Üniversitesi, Buldan Meslek Yüksekokulu, Muhasebe Bölümü, sozdemir15041976@gmail.com
} 


\section{GíRİș}

İç denetim, bir kurumun faaliyetlerini geliştirmek ve kuruma değer katmak amaciyla bağımsız ve objektif bir güvence ve danışmanlık faaliyeti olarak tanımlanmaktadır. Kurumun risk yönetimi, iç kontrol ve kurumsal yönetim süreçlerinin etkin şekilde işlemesini sağlamak amacıyla sistemli bir yaklaşım oluşturarak kurumun hedeflerine ulaşmasına yardımcı olur (Aykaç, 2005: 453). İç denetim iç kontrolün farklı bir boyutunu oluşturmaktadır. İç denetim yönetime yönelik bir hizmettir ve örgütün iç kontrol sisteminin bir parçasıdır (Korkmaz, 2007: 8). İç denetimin en temel işlevi işletmedeki iç kontrol mekanizmalarının sağlıklı bir şekilde işlemesini sağlamaktır (Yılancı, 2006: 14).

Uluslararası Yüksek Denetim Kurumları Teşkilatı (INTOSAI) iç kontrolü kurumun misyonu doğrultusunda riskleri göğüslemek ve makul bir güvence sağlamak üzere tasarlanan ve kurumun yönetimi ve personeli tarafindan hayata geçirilen tamamlayıcı bir süreç olarak tanımlamaktadır (INTOSAI GOV 9100, 2004: 6).

İç kontrol, kurum kaynaklarının etkili, ekonomik, verimli ve kurumun amaçlarına uygun bir şekilde kullanılması, iş ve işlemlerin mevzuata uygunluğu, faaliyetler hakkında düzenli, zamanında ve güvenilir bilgi üretilmesi, kurumun varlıklarının korunması, yolsuzluk ve usulsüzlüklerin önlenmesi konularında yeterli ve makul güvence sağlayan bir yönetim aracidır (Tümer, 2010: 11)

İç kontrol mekanizmalarının doğru işlemesi için bazı iç kontrol modelleri oluşturulmuştur. $\mathrm{Bu}$ modellerden en bilinenleri şunlardır; COSO (Treadway KomisyonuCommittee of Sponsoring Organizations), Kanada'nın CoCo (Kontrol Kriterleri-Criteria of Control), İngiltere'nin Turnbull Report, Almanya'nın Kontrag, Avustralya/Yeni Zelanda Risk Yönetim Standardı (AS/NZS 4360), Güney Afrika'nın King Report (Moeller, 2005; Pickett, 2003). Bu çalışmanın amacı; iç kontrol modellerinden COSO ile SOA Kanunundan sonra SEC'in şirketlerinden düzenli olarak istediği ICFR arasındaki ilişkiyi ortaya koymaktır.

\section{COSO}

COSO, tüm dünyada örgütsel yönetim, iş etiği, iç kontrol, kurumsal risk yönetimi (Enterprise Risk Management - ERM), hile ve finansal raporlama gibi kritik konularda rehberlik hizmeti sağlayan bağımsız bir kuruluştur (www.coso.org). Komitenin kurucu başkanı James C. Treadway olması dolayısıyla popüler ismi "Treadway Komisyonu"dur.

1985 y1lında Hileli Mali Raporlama Üzerine Ulusal Komisyonu (National Commission on Fraudulent Financial Reporting) desteklemek için kurulan COSO, hileli mali raporlamaya sebep olan geçici faktörleri saptamaya çalışan bağımsız bir özel sektör girişimidir. Aynı zamanda bağımsız denetçileri, devlet kurumları, SEC ve diğer düzenleyiciler ile eğitim kurumları için tavsiyeler oluşturmaktadır (http://www.coso.org/aboutus.htm).

Ulusal komisyon 5 ana kuruluş tarafindan desteklenmektedir. Bunlar;

- Amerikan Muhasebeciler Birliği (American Accounting Association-AAA)

- Amerikan Sertifikalı Muhasebeciler Kurumu (American Institute of Certified Public Accountants-AICPA)

- Finansal Yöneticiler Kurumu (Financial Executives International -FEI)

- İç Denetçiler Enstitüsü (TheInstitute of InternalAuditors-IIA)

- Ulusal Muhasebeciler Birliği (National Association of Accountants) (yeni adiyla Yönetim Muhasebecileri Enstitüsü-The Institute of Management Accountants-IMA) 
Tamamıyla bağımsız olan bu kurumların yanında Ulusal Komisyon sektörden, devlet muhasiplerinden, yatırım şirketlerinden ve New York Borsasından (NYSE) temsilciler içermektedir.

COSO'nun amac1; kurumsal risk yönetimi (ERM), iç kontrol ve hileyi engelleme gibi birbiri ile ilişkili üç konu üzerine düşünce liderliği sağlamaktır. COSO’nun 1992 yılında yayımladığı "Internal Control-Integrated Framework" adlı rapor yayınlandığı tarihten itibaren işletmelere iç kontrol sistemini değerlendirme hususunda yardımcı olmuştur. Bu çerçeve zaman içinde devlet, kurallar, düzenlemeler ile bütünleşerek, işletmelerin daha iyi bir şekilde iç kontrol çalışmalarını sürdürmeleri ve saptadıkları hedefleri başarmaları konusunda onlara rehber olmuştur (http://www.coso.org/aboutus.htm).

Ancak geçen yıllar risk yönetimi konusunun önemini arttırmıştır. Riski etkili bir şekilde saptamak, değerlendirmek ve yönetmek için sağlam bir çerçeve ihtiyacı doğmuştur. Bunun için COSO, 2001 yılında Price Waterhouse Coopers ile bu ihtiyacı karşılamak için bir proje başlatmıştır. Bu süreç devam ederken kamuoyu tarafından tanınan büyük şirketlerin skandal ve başarısızlıkları gündeme gelmiştir. 2002 yılında ABD'de Sarbanes-Oxley Yasası yürürlüğe girerken, diğer ülkelerde de benzer kanunlar yasalaşmıştır (COSO ERM, 2004). Yaşanan bu gelişmeler sağlam bir risk yönetimi çerçevesi ihtiyacını kaçınılmaz kılmıştır. Çalışmaların sonucunda Komisyon 2004 yılının Eylül ayında "Enterprise Risk ManagementIntegrated Framework (ERM-Kurumsal Risk Yönetimi)" yayımlamıştır. COSO, 2009 yılı ile birlikte kurumsal risk yönetimi konusunda birçok rapor yayınlamıştır.

Her ne kadar COSO ERM 1992 yılındaki raporun genişletilmiş şekli olarak görülse de, ERM "COSO I" olarak bilinen "Internal Control-Integrated Framework" raporun yerini almamaktadır. COSO ERM risk yönetimi ile iç kontrolü birleştirmektedir. İç kontrolü genişleterek risk yönetimi konusunda daha sağlam ve kapsamlı bir odak oluşturmaya çalışmaktadır. COSO ERM, şirketlerin hem iç kontrol ihtiyaçlarını tatmin etmeleri, hem de daha kapsamlı bir risk yönetimi sürecini yaşamaları için gereklidir (COSO ERM, 2004).

COSO ERM; bir işletmenin yöneticileri, yönetimi ve diğer personeli tarafindan strateji oluşturmak için uygulanan, işletmeyi etkileyebilecek muhtemel olayları tanımlamak için oluşturulmuş, riski yöneten, işletmenin amaçlarını başarmak için akılcı güven sağlayan bir süreçtir. COSO ERM, düzenlemelere ve hukuka uygun ve etkili raporlamayı sağlayarak, işletmenin saygınlığına zarar vermekten kaçınır. İşletmeleri faaliyetleri süresince karşılaşacakları sürprizlerden koruyarak, yapmak istedikleri konusunda onlara yardımcı olmaya çalışır (COSO ERM, 2004).

COSO 2013 yılında İç Kontrol-Bütünleşik Çerçeveyi yayınladıktan sonra, 15 Aralık 2014 tarihinde 1992 yılında yayınlanan İç Kontrol-Bütünleşik Çerçeve yürürlükten kaldırılmıştır. 2006 yılında yayınlanan "Küçük Halka Açık Şirketler için Rehber (Internal Control Over Financial Reporting-Guidance for Smaller Public Companies) de aynı tarihte yürürlükten kaldırılmıştır. COSO yetkilileri Kurumsal Risk Yönetiminin (ERM) iç kontrolden daha kapsamlı olmakla birlikte iç kontrolün ayrılmaz bir parçası olduğunu kabul etmektedir. $\mathrm{Bu}$ yüzden 2004 yılında yayınlanan Kurumsal Risk Yönetimi (COSO ERM) ve son yayınlanan İç Kontrol raporunun birbirini tamamladığını vurgulamaktadırlar (McNally, 2013: 7). 


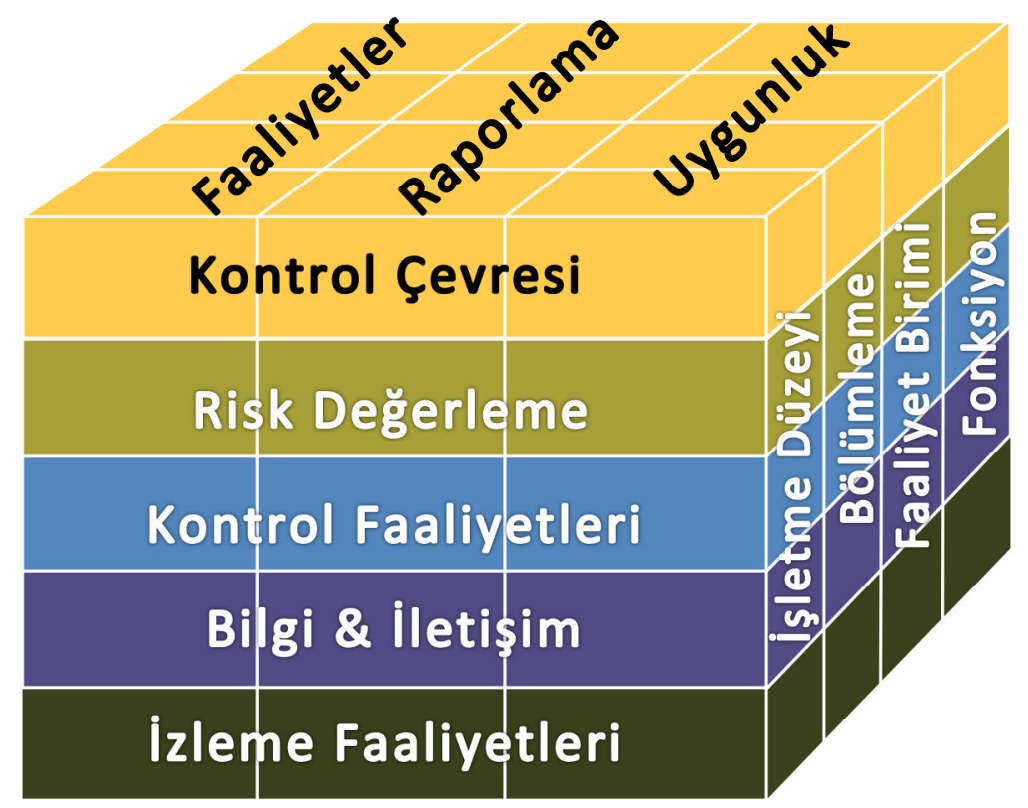

Kaynak: COSO, 2013.

Şekil 1: COSO Kübü

COSO raporunda iç kontrolün unsurlarını kontrol ortamı, risk değerleme, kontrol faaliyetleri, bilgi ve iletişim, izleme şeklinde sıralamaktadır. Kontrol ortamı; iç kontrol sisteminin tamamına etki eden ve iç kontrolü uygulamak için ihtiyaç duyulan yapı, süreç ve standartlar bütünüdür. Risk değerleme; işletmenin karşı karşıya kalacağı iç ve diş kaynaklardan gelen çeşitli riskleri tanımlar ve analiz eder. Kontrol faaliyetleri; işletmenin amaçlarını gerçekleştirebilmesi için karşılaştığı riskleri azaltacak olan yönetim kademesine yardımcı olacak politika ve prosedürlerdir. Bilgi; amaçlara ulaşmak için gerekli bilgilerdir. İletişim ise; ihtiyaç duyulan bilgiyi sağlayan ve paylaşan aralıksız ve tekrarlayan bir süreçtir. İzleme ise; iç kontrolün diğer unsurlarının başarısını değerlendirme sürecidir(COSO, 2013: 45). COSO 2013 yılında yayınladığı çerçevede bu bağlamda 17 temel prensip yayınlamıştır. Bu prensipler tarafların etkili iç kontrolü daha iyi anlamalarına yardımcı olacaktır. Böylece etkinliği değerlendirirken bilinçli muhakeme yapma şansları olacaktır (TheUpdatedCoso, 2013: 4). 
Tablo 1: İç Kontrolü Başarmak İçin 17 Temel Prensip ve Odak Noktaları

\begin{tabular}{|c|c|c|c|}
\hline \multicolumn{4}{|c|}{ Kontrol Ortamı } \\
\hline \multicolumn{2}{|r|}{ Prensipler } & \multicolumn{2}{|r|}{ Odak Noktaları } \\
\hline \multirow[t]{4}{*}{1} & \multirow{4}{*}{$\begin{array}{l}\text { İşletme dürüstlük ve etik değerlere bağlı } \\
\text { olmalıdır. }\end{array}$} & 1 & Üstteki ortamı belirleme. \\
\hline & & 2 & Uygulama standartlarını oluşturma. \\
\hline & & 3 & $\begin{array}{lll}\text { Uygulama } & \text { standartlarına } & \text { uygunluğu } \\
\text { değerlendirme. } & & \end{array}$ \\
\hline & & 4 & Sapmaları zamanında belirleme. \\
\hline \multirow[t]{4}{*}{2} & \multirow{4}{*}{$\begin{array}{l}\text { Yönetim kurulu üyeleri yönetimden bağımsız } \\
\text { olmalı ve iç kontrole ilişkin gözetim } \\
\text { sorumluluğunu bilmeli ve uygulamalıdır. }\end{array}$} & 5 & Gözetim sorumluluklarını oluşturma. \\
\hline & & 6 & Konuyla ilişkili uzmanlık alanları uygulanması. \\
\hline & & 7 & Bağımsız olarak faaliyette bulunma. \\
\hline & & 8 & $\begin{array}{l}\text { Kontrol Ortamı, Risk Değerleme, Kontrol } \\
\text { Faaliyetleri, Bilgi ve İletişim, İzleme üzerine } \\
\text { gözetim sağlama. }\end{array}$ \\
\hline \multirow[t]{3}{*}{3} & \multirow{3}{*}{$\begin{array}{l}\text { Yönetim, yönetim kurulu ile birlikte } \\
\text { yönetimin yapısı, raporlamalarını hedefleri } \\
\text { doğrultusunda yetki ve sorumluluklarını } \\
\text { oluşturmalıdır. }\end{array}$} & 9 & İ̀sletmenin tüm yapılarını dikkate alma. \\
\hline & & 10 & Raporlama yollarını oluşturma. \\
\hline & & 11 & $\begin{array}{l}\text { Yetki ve sorumlulukları tanımlama, } \\
\text { görevlendirme ve sinırlandırma. }\end{array}$ \\
\hline \multirow[t]{4}{*}{4} & \multirow{4}{*}{$\begin{array}{l}\text { İşletme, hedefleri doğrultusunda yetkili } \\
\text { bireyleri geliştirmeli ve devamlılığını } \\
\text { sağlamalıdır. }\end{array}$} & 12 & Politika ve uygulamaları oluşturma. \\
\hline & & 13 & $\begin{array}{l}\text { Becerileri değerlendirme ve yetersizlikleri ele } \\
\text { alma. }\end{array}$ \\
\hline & & 14 & Bireyleri elde etme, geliştirme ve elde tutma. \\
\hline & & 15 & $\begin{array}{l}\text { Birbirinin yerini almak için hazırlama ve } \\
\text { planlama. }\end{array}$ \\
\hline \multirow[t]{5}{*}{5} & \multirow{5}{*}{$\begin{array}{l}\text { İşletme, hedefleri doğrultusunda iç kontrol } \\
\text { yükümlülükleri için sorumlu bireyleri işletme } \\
\text { bünyesinde tutmalıdır. }\end{array}$} & 16 & $\begin{array}{l}\text { İşletme yapısı, yetki ve sorumlulukları yoluyla } \\
\text { hesap verilebilirliği uygulama. }\end{array}$ \\
\hline & & 17 & $\begin{array}{l}\text { Performans ölçümlerini, ödül ve teşvikleri } \\
\text { oluşturma. }\end{array}$ \\
\hline & & 18 & $\begin{array}{l}\text { Devam eden ilgili konularda da performans } \\
\text { ölçümlerini, ödül ve teşvikleri oluşturma. }\end{array}$ \\
\hline & & 19 & Fazla baskıyı göz önüne alma. \\
\hline & & 20 & $\begin{array}{l}\text { Performans ve ödülleri değerlendirme veya } \\
\text { bireyleri disipline etme. }\end{array}$ \\
\hline \multicolumn{4}{|c|}{ Risk Değerleme } \\
\hline 6 & 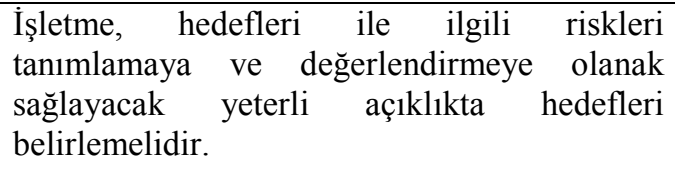 & & \\
\hline & \multirow[t]{4}{*}{-Operasyonel Hedefler } & $21 \mathrm{a}$ & Yönetimin seçimlerini yansıtma. \\
\hline & & $22 \mathrm{a}$ & Risk toleransını dikkate alma. \\
\hline & & 23 & $\begin{array}{l}\text { Finansal performans hedeflerini ve işlemleri } \\
\text { kapsama. }\end{array}$ \\
\hline & & 24 & Kaynakları işlemek için bir temel oluşturma. \\
\hline
\end{tabular}




\begin{tabular}{|c|c|c|c|}
\hline & \multirow[t]{3}{*}{-Diş Finansal Raporlama Hedefleri } & $21 b$ & Geçerli muhasebe standartlarına uygun olma. \\
\hline & & $22 b$ & Önemliliği dikkate alma. \\
\hline & & 25 & İşletme faaliyetlerini yansıtma. \\
\hline & \multirow[t]{3}{*}{-Dış Finansal Olmayan Raporlama Hedefleri } & $21 \mathrm{c}$ & $\begin{array}{lll}\text { Dişarıdan oluşturulmuş } & \text { standartlara } & \text { ve } \\
\text { çerçevelere uygun olma. } & & \end{array}$ \\
\hline & & $22 \mathrm{c}$ & İstenilen doğruluk derecesine uygun olma. \\
\hline & & 25 & İşletme faaliyetlerini yansıtma. \\
\hline & \multirow[t]{3}{*}{-İç Raporlama Hedefleri } & $21 \mathrm{a}$ & Yönetimin seçimlerini yansıtma. \\
\hline & & $22 \mathrm{c}$ & İstenilen doğruluk derecesine uygun olma. \\
\hline & & 25 & İşletme faaliyetlerini yansıtma. \\
\hline & \multirow[t]{2}{*}{-Uygunluk Hedefleri } & $21 d$ & Dışsal kanun ve düzenlemeleri yansıtma. \\
\hline & & $22 \mathrm{a}$ & Risk toleransını dikkate alma. \\
\hline \multirow[t]{5}{*}{7} & \multirow{5}{*}{$\begin{array}{l}\text { İşletme, risklerin nasıl yönetilebileceğini } \\
\text { belirlemeli ve hedeflerini gerçekleştirebilmek } \\
\text { için riskleri tanımlamalıdır. }\end{array}$} & 26 & $\begin{array}{l}\text { İşletme, bağlı ortaklık, bölüm, faaliyet birimi ve } \\
\text { fonksiyonel seviyede kapsama. }\end{array}$ \\
\hline & & 27 & İç ve dış faktörleri analiz etme. \\
\hline & & 28 & Yönetimin uygun kademelerini içerme. \\
\hline & & 29 & Tanımlanmış risklerin önemini tahmin etme. \\
\hline & & 30 & Risklere nasıl yanıt verileceğine karar verme. \\
\hline \multirow[t]{4}{*}{8} & \multirow{4}{*}{$\begin{array}{l}\text { İşletme, finansal raporlama hedeflerine } \\
\text { ulaşmak için risklerin değerlendirilmesinde, } \\
\text { hile olasılığını dikkate almalıdır. }\end{array}$} & 31 & Hilenin çeşitli tiplerini göz önünde bulundurma. \\
\hline & & 32 & Teşvik ve baskıları değerlendirme. \\
\hline & & 33 & Firsatları değerlendirme. \\
\hline & & 34 & Tutum ve rasyonelliği değerlendirme. \\
\hline \multirow[t]{3}{*}{9} & \multirow{3}{*}{$\begin{array}{l}\text { İşletme, iç kontrol sistemine önemli düzeyde } \\
\text { etki edebilecek değişiklikleri belirlemeli ve } \\
\text { tanımlamalıdır. }\end{array}$} & 35 & D1ş çevredeki değişiklikleri değerlendirme. \\
\hline & & 36 & İş modelindeki değişiklikleri değerlendirme. \\
\hline & & 37 & Liderlikteki değişiklikleri değerlendirme. \\
\hline \multicolumn{4}{|c|}{ Kontrol Faaliyetleri } \\
\hline \multirow[t]{6}{*}{10} & \multirow{6}{*}{$\begin{array}{l}\text { İşletme, kabul edilebilir seviyedeki hedefleri } \\
\text { başarmak amacıyla riskleri azaltmayı } \\
\text { sağlayacak kontrol faaliyetleri seçmeli ve } \\
\text { geliştirmelidir. }\end{array}$} & 38 & Risk değerleme ile birleşme. \\
\hline & & 39 & Belirli işletme faktörlerini dikkate alma. \\
\hline & & 40 & İlişkili işletme süreçlerine karar verme. \\
\hline & & 41 & $\begin{array}{l}\text { Kontrol faaliyet türlerinin bir karışımını } \\
\text { değerlendirme. }\end{array}$ \\
\hline & & 42 & $\begin{array}{l}\text { Hangi seviyedeki faaliyetlerin uygulanabilir } \\
\text { olduğunu dikkate alma. }\end{array}$ \\
\hline & & 43 & Görevler ayrılı̆̆ına değinme. \\
\hline \multirow[t]{3}{*}{11} & \multirow[t]{3}{*}{$\begin{array}{lccr}\text { İşletme, } & \text { hedeflerini } & \text { gerçekleştirmeyi } \\
\text { sağlayacak } & \text { teknolojik } & \text { genel } & \text { kontrol } \\
\text { faaliyetleri seçmeli ve geliştirmelidir. } & \end{array}$} & 44 & $\begin{array}{l}\text { Teknoloji genel kontrolleri ve işletme } \\
\text { süreçlerindeki teknoloji arasındaki bağımlılığı } \\
\text { belirleme. }\end{array}$ \\
\hline & & 45 & $\begin{array}{l}\text { İlgili teknolojik altyap1 kontrol faaliyetlerni } \\
\text { oluşturma. }\end{array}$ \\
\hline & & 46 & $\begin{array}{l}\text { İlgili güvenlik yönetim süreç } \\
\text { faaliyetlerini oluşturma. }\end{array}$ \\
\hline
\end{tabular}




\begin{tabular}{|c|c|c|c|}
\hline & & 47 & $\begin{array}{l}\text { İlgili teknolojik tedarik, gelişme ve bakım } \\
\text { süreçleri kontrol faaliyetlerini oluşturma. }\end{array}$ \\
\hline \multirow[t]{6}{*}{12} & \multirow{6}{*}{$\begin{array}{l}\text { İşletme, oluşturulması beklenen politikalar ve } \\
\text { politikaları uygulamaya geçirecek prosedürler } \\
\text { yoluyla kontrol faaliyetlerini etkin } \\
\text { kullanmalıdır. }\end{array}$} & 48 & $\begin{array}{l}\text { Yönetim yönergelerini yayılımını desteklemek } \\
\text { için politika ve prosedürler oluşturma. }\end{array}$ \\
\hline & & 49 & $\begin{array}{l}\text { Politika ve prosedürleri uygulamak için } \\
\text { yükümlülük ve sorumluluk oluşturma. }\end{array}$ \\
\hline & & 50 & Zamanında yerine getirme. \\
\hline & & 51 & Düzeltici önlem alma. \\
\hline & & 52 & Yetkili personel kullanma. \\
\hline & & 53 & Politika ve prosedürleri yeniden değerlendirme. \\
\hline \multicolumn{4}{|c|}{ Bilgi ve İletişim } \\
\hline \multirow[t]{5}{*}{13} & \multirow{5}{*}{$\begin{array}{l}\text { İşletme, iç kontrol fonksiyonlarını destekleyen } \\
\text { ilişsili ve kaliteli bilgi meydana getirmeli ve } \\
\text { kullanmalıdır. }\end{array}$} & 54 & Bilgi gereksinimlerini belirleme. \\
\hline & & 55 & İç ve dış veri kaynaklarını ele geçirme. \\
\hline & & 56 & İlgili verileri bilgi haline getirme. \\
\hline & & 57 & Süreç boyunca kaliteyi devam ettirme. \\
\hline & & 58 & Fayda ve maliyetleri dikkate alma. \\
\hline \multirow[t]{4}{*}{14} & \multirow{4}{*}{$\begin{array}{l}\text { İşletme, örgüt içinde iç kontrol fonksiyonlarını } \\
\text { destekleyecek yeterlilikte, iç kontrole dair } \\
\text { sorumluluk ve hedeflerini içeren bilgilerin } \\
\text { alışverişinde bulunmalıdır. }\end{array}$} & 59 & İç kontrol bilgilerini iletme. \\
\hline & & 60 & Yönetim kurulu ile iletişim kurma. \\
\hline & & 61 & Ayrı iletişim hattı sağlama. \\
\hline & & 62 & İlgili iletişim yöntemini seçme. \\
\hline \multirow[t]{5}{*}{15} & \multirow{5}{*}{$\begin{array}{l}\text { İşletme, örgüt } \begin{array}{c}\text { dişında iç } \\
\text { fonksiyonlarına etki }\end{array} \begin{array}{r}\text { kontrol } \\
\text { edecek }\end{array} \text { noktalarda } \\
\text { iletişim kurmalıdır. }\end{array}$} & 63 & Örgüt dışındaki tarafla iletişime girme. \\
\hline & & 64 & Gelen iletişimi kolaylaştırma. \\
\hline & & 65 & Yönetim kurulu ile iletişim kurma. \\
\hline & & 66 & Ayrı iletişim hattı sağlama. \\
\hline & & 67 & İlgili iletişim yöntemini seçme. \\
\hline \multicolumn{4}{|c|}{ İzleme } \\
\hline \multirow[t]{7}{*}{16} & \multirow{7}{*}{$\begin{array}{l}\text { İşletme, iç kontrol bileşenlerinin güncel ve } \\
\text { fonksiyonel olup olmadığını belirlemek için } \\
\text { devam eden ve bağımsız değerlendirmeleri } \\
\text { seçmeli, geliştirmeli ve uygulamalıdır. }\end{array}$} & 68 & $\begin{array}{l}\text { Devam eden ve bağımsız değerlendirmelerin } \\
\text { bileşimini göz önünde bulundurma. }\end{array}$ \\
\hline & & 69 & Değişim hızını göz önünde bulundurma. \\
\hline & & 70 & Temel anlayış1 oluşturma. \\
\hline & & 71 & Bilgili personel kullanma. \\
\hline & & 72 & İş süreçleriyle bütünleşme \\
\hline & & 73 & Kapsam ve sıklığı ayarlama. \\
\hline & & 74 & Tarafsız değerlendirme. \\
\hline \multirow[t]{3}{*}{17} & \multirow{3}{*}{$\begin{array}{l}\text { İç kontrole ilişkin eksiklikler tanımlanmalıve } \\
\text { zamanında düzeltici önlemleri alacak kişiler } \\
\text { ile ilgili yönetim ve kurul üyelerine } \\
\text { bildirilmelidir. }\end{array}$} & 75 & Sonuçları değerlendirme. \\
\hline & & 76 & $\begin{array}{l}\text { Eksiklikleri düzeltici önlemleri alacak kişilere } \\
\text { ve ilgili yönetim kurul üyelerine bildirilme. }\end{array}$ \\
\hline & & 77 & Düzeltici önlemleri izleme. \\
\hline
\end{tabular}

Kaynak: TheUpdatedCOSOInternal Control Framework 2013, 7-10.

COSO’nun 2013 yılında yayınladığı çerçevesi yıllar alan önemli bir çalışmanın sonucudur. Globalleşen dünyada düzenleyici tarafların ve paydaşların işletmelerden daha 
yüksek beklentileri ortaya çıkmaktadır. Kamu gözetimi, risk yönetimi ve hilenin önlenmesi gibi konular önem kazanmıştır. Bu gelişmeler yaşanırken, 1992 yılında çıkarılan İç Kontrol Çerçevesinden bu yana da beklentilerde artışlar görülmüştür. 1992 yılındaki Çerçeveye bazı eleştiriler de yapılmıştır. Orijinal Çerçeve çok ayrıntılı ve fazlasıyla uzun iç kontrol bilgileri içermekteydi. Ayrıca orijinal Çerçevenin içine yerleştirilmiş iç kontrol kavramları bulunmasına rağmen, prensipler detaylara saklanmış durumdaydı. Uygulayıcılar temel olarak Çerçeveyi finansal raporlama için iç kontrol olarak kullanmalarına rağmen, aslında Çerçeve faaliyetler, uygunluk ve finansal raporlama olmak üzere üç ana kategoriyi kapsamaktadır (Guide ICFR, 2013: 2).

2013 yılında yayınlanan çerçevede COSO yetkilileri, özünde orijinal çerçevede ana hatları ve prensiplerin kalacağını vurgulamışlardır. Böylece COSO, 1992 yılındaki çerçevenin yerini alan orijinal çerçeveyi kullanmaya devam edecektir. Bu geçiş sürecinde COSO, geçerli 1992 çerçevesinin kullanımının devam edeceğine inanmaktadır. İşletmeler, geçiş sürecinde dış raporlama için geliştirilen yeni çerçeveyi takip etmektedirler. Ancak işletmelerin çerçevenin 1992 versiyonunu mu yoksa 2013 versiyonunu mu kullanacaklarına açıkça karar vermeleri gerekmektedir (McNally, 2013: 2).

Yaşanan bu gelişmelerin etkisiyle işletmelerin etkililiğini ve verimliliğini geliştirecek firsatları belirlemek amacıyla periyodik olarak finansal raporlama ile ilgili iç kontrol sistemlerini yeniden değerlendirmeleri gerekmektedir. Geliştirilen 2013 Çerçevesinde orijinal metindeki prensipler daha açık bir şekilde yer almaktadır. Bu çerçeve, 20 yıldan uzun bir süredir çevresel değişiklikleri yönetmenin ve çerçevenin kullanım ve uygulamalarını kolaylaştırmanın en etkili yolu olmuştur (McNally, 2013: 2).

2013 Çerçevesi aynı zamanda Sarbanes Oxley Kanunu'nun (Sarbanes Oxley ActSOA) sınırları ve kapsamları bakımından yönetime kolaylık sağlamaktadır. Örneğin, bazı işletmeler 1992 Çerçevesindeki uygulamaları tam anlamıyla belgelendirememektedir. Bazıları ise orijinal metindeki açıklamaları yanlış uygulama veya yanlış yorumlayabilmektedirler. Böylece bir veya daha fazla prensibe ilişkin uygun bir değerlendirme süreci mümkün olmamaktadır. Güncellenmiş Çerçeve, kontrol ortamı, risk değerlendirme, kontrol faaliyetleri, bilgi ve iletişim, izleme gibi iç kontrolün beş temel unsurunun her birinin odak noktalarını desteklemiş ve prensiplerini geliştirmiştir. Böylece, yönetim kademeleri iç kontrole ilişkin etkinlikleri belirtmek ve ilgili konuları tanımlamakta daha başarılı olacaktır. Aynı zamanda finansal raporlama konusunda önemli zayıflığı engellemeye de yardımcı olmaktadır (McNally, 2013: 3). Önemli zayıflık, şirketin yıllık ya da ara dönem finansal tablolarında yer alan bir yanlış beyanın engellenememesi veya zamanında tespit edilememesi ihtimali gibi finansal raporlama üzerindeki iç kontrol kapsamında yer alan bir eksiklik veya eksikliklerin tamamıdır (Uzay ve Gönen, 2012: 47). SOA’ya göre Amerikan Sermaye Piyasası Kurulu (SEC) şirket üst yönetimlerinin yıllık iç kontrol değerlendirmelerini yaparken yani Finansal Raporlama ile ilgili İç Kontrol Raporunu (Internal Control over Financial Reporting-ICFR) hazırlarken, COSO iç kontrol çerçevelerinden yararlanabileceğini belirtmiştir (Uzay ve Gönen, 2012: 49).

\section{Finansal Raporlama İle İlgili İç Kontrol}

ABD’de 1977 yılından beri kamu kurumlarının, genel kabul görmüş muhasebe ilkelerine göre hazırlanmış finansal tablolarına makul güvence sağlayacak bir iç kontrol sisteminin oluşturulması istenmektedir. Bu durum 2002 yılında çıkarılan Sarbanes Oxley Kanunu ile yasal bir zemine kavuşmuştur. Bu Kanun, sermaye piyasasına kayıtlı şirketlerde yönetim kademesinin ICFR düzenlemesi ve bu raporu kamuoyuna açıklaması zorunluluğu getirilmiştir. Ayrıca Kanuna göre söz konusu raporların bağımsız bir denetçi tarafından denetimden geçirilmesini gerektirmektedir (Guide ICFR, 2013: 1). Bağımsız denetçiler ICFR 
denetimlerinde yoğun olarak finansal kontrollere değinmektedirler (Uzay, Gönen, 2012: 44). Bir şirketin ICFR'yi yayınlaması ve yayınlanan raporların da bağımsız denetime tabi olması hazırlanan finansal raporların güvenirliğini arttıracaktır. Böylece bu şirketlerin iç finansal raporlama ve iç kontrol zayıflıkları da ortadan kalkacaktır (Uzay, Gönen, 2012: 43).

Dünyada yaşanan skandallardan sonra 2002 y1lında yürürlüğe giren Sarbanes Oxley Kanunu (SOA) yatırımcıların sermaye piyasalarına olan güvenini yeniden kazandırmayı amaçlamaktaydı (Uzay, Gönen, 2012: 45). Bu Kanunla kurulan Kamu Gözetim Kurulu (Public Company Accounting Oversight Board-PCAO) tarihte ilk kez kamu şirketlerinin diş ve bağımsız gözetiminin yapılması gerektiğini belirtmiştir (http://pcaobus.org/About/Pages/default.aspx).

Finansal Raporlama ile ilgili İç Kontrol Raporu (Internal Control over Financial Reporting-ICFR), iç kontrolün daha geniş kapsamlı bir parçasıdır. ICFR, özellikle finansal raporlamaya ilişkin riskleri gidermek için tasarlanmış kontrollerdir. Daha basit bir ifadeyle, kamu kurumuna ait bir ICFR, USGAAP'e göre hazırlanmış ve güvenilir şirket finansal tablolarına "makul güvence" sağlamak için tasarlanmış kontrollerden oluşur. Bir finansal tabloda matematiksel hatalar, mevzuata uygun olmayan durumlar veya kasten yanıltıcı bilgi verilmesi gibi yanlışlıklar meydana gelebilir. ICFR sistemi bu olasılıkları gidermelidir (Guide ICFR, 2013: 2).

Finansal raporlamaya yönelik iç kontroller; kayıtların, işlemlerin ve varlıkların karakterlerini tam ve doğru yansıtacak detayları içermesi, finansal tabloların USGAAP'a uygun hazırlanması için gerekli tüm işlemlerin kaydedildiğine ve şirketin gelir ve harcamalarının şirket yönetimi tarafından onaylandığına dair makul güvencenin verilebilmesi ve şirketin finansal tablolara önemli derecede etki edebilecek varlıklarının onaylanmadan alımının, kullanımının veya elden çıkarımının engellendiğine veya zamanında tespit edildiğine yönelik makul güvencenin verilebilmesi gibi prosedürleri içerir (PWC, 2004: 12).

Amerikan Sermaye Piyasası Kurulu (SEC) ICFR'yi; “USGAAP'e göre bağımsız amaçlar için finansal tabloların hazırlanması ve finansal raporların güvenilirliği için makul güvence sağlamak üzere üst düzey şirket yöneticileri veya çalışanları tarafindan yürütülen bir süreç” olarak tanımlamaktadır (Guide ICFR, 2013: 4).

Uluslararası bağımsız denetim standartları, bir bütün olarak finansal tabloların hata veya hile kaynaklı önemli bir yanlışlık içermesi hususunda denetçinin görüşüne dayanak oluşturacak makul bir güvence elde etmesini zorunlu kılmaktadır. Makul güvence yüksek bir güvence seviyesidir. Makul güvence, denetçinin finansal tabloların önemli bir yanlışlık içermesine rağmen duruma uygun olmayan bir görüş vermesi riski ile karşı karşıya kalındığında, ancak kabul edilebilir düşük bir seviyeye indirecek yeterli ve uygun denetim kanıtı elde edilmesiyle sağlanmış olur. Ancak denetçinin ulaştığı sonuçları ve görüşünü dayandırdığı çoğu denetim kanıtının kesin olmasından çok ikna edici olması gibi sebeplerle makul güvence mutlak bir güvence seviyesi olarak kabul edilmemektedir (Auditing Standard No:5, A1-4, A1-5).

ICFR'nin hiçbir sistemi mutlak güvence sağlayamaz. İç kontrol insanlar tarafından uygulanır ve kaçınılmaz olarak da hatalar meydana gelmektedir. Henüz bütün olası hataları belirleyecek ve önleyecek bir kontrol sistemi oluşturulmamıştır. Bunun yanında, hile, gizli anlaşma gibi kasıtll suiistimalleri önlemek, ancak iyi oluşturulmuş kontrol sistemleri ile mümkündür. Dolayısıyla, kontrol sistemleri kanunlara uygun hazırlanmış ve güvenilir finansal tablolara mutlak değil ama makul güvence sağlar. Makul güvence, sermaye piyasası kanunlarında, kendi işlerinin yürütülmesinde ihtiyatlı yetkilileri tatmin edecek güvence derecesi olarak tanımlamaktadır (Guide ICFR, 2013: 5). 
ICFR'nin önemli bir unsuru "kontrol ortamı"dır. Kontrol ortamı işletmenin tüm değerlerini ve yapısını içinde barındırır. Kontroller, güvenilir finansal raporlamaya bağlı, doğruluk ve etik değerleri önemseyen bir işletme ise, kuvvetle muhtemel başarılı olacak güvenilir finansal raporlama oluşturulmak için tasarlanmıştır. Bazı göstergeler olumlu bir kontrol ortamının, etkili kontrollere destek veren üst düzey yönetime, kurum içi uygun bir iş ahlakı uygulamasına ve etik değerler ve çalışan hakları ile ilgili programlara sahip olduğunu göstermektedir (Guide ICFR, 2013: 5).

ICFR'deki bir diğer önemli unsur ise "kontrol faaliyetleri"dir. Kontrol faaliyetleri finansal raporlama riskini azaltmak üzere tasarlanmış belirli politikalar ve prosedürlerdir. Kamu kurumlarındaki çeşitleri farklılaşmakla beraber kontrol faaliyetleri üç kavramdan oluşur. Bunlar; görevler ayrılığı (segregation of duties), önleyici ve saptayıcı kontroller (preventive and detective controls) ve kurum boyutunda ve süreç boyutunda (entitylevelandprocess-levelcontrols) kontrollerdir (Guide ICFR, 2013: 5).

Kurumlarda ICFR uygulanmasından yönetim kademeleri sorumludur. ICFR işletmede bireyler tarafından yürütülmektedir. Ancak önemli olan, ICFR'nin gözetim ve içeriğine hakim çalışanlar tarafından yürütülmesidir. Her kademedeki yöneticiler kendi sorumlu oldukları alanlardaki kontrolünden sorumludur.

2002 yılında kurulan Kamu Gözetim Kurulu (Public Company Accounting Oversight Board- PCAOB), Amerikan Sermaye Piyasası Kurulu'na (SEC) kayıtlı şirketlerin SOA'a uygunluk ile ilgili yıllık olarak bir rapor sunulması istemiştir (Uzay, Gönen, 2012: 45). Sarbanes Oxley Yasasının 103, 302 ve 404 numaralı maddeleri ICFR'ye ilişkin hükümleri kapsamaktadır.

Yasanın 103 numaralı bölüme göre; şirketin bağımsız denetimini gerçekleştiren firmanın yönetim raporunu değerlendirmesi gerekmektedir (PWC, 2004: 8). SOA Bölüm 404 ile şirket yönetimlerine, şirketin finansal raporlamasına yönelik iç kontrollerinin yeterliliğini değerlendirme zorunluluğu getirmiştir. Sonuçta; Yasanın 302 ve 404 numaralı maddeleri çerçevesinde şirketlerin finansal raporlamaları üzerindeki risklerin belirlenmesi, belirlenen risklere ilişkin kontrollerin kaydedilmesi ve değerlendirilmesi zorunlu tutulmuş, kontrollerin etkinliğinden şirket yöneticileri sorumlu tutulmuştur. Yasa ile birlikte gelen ağır cezai yaptırımlar şirket yöneticileri başta olmak üzere tüm çıkar sahiplerini ve bağımsız denetçileri derinden etkilemiş, yasaya tabi tüm şirketler finansal raporlamaya yönelik iç kontrollerinin iyileştirilmesi için kapsamlı projeler başlatmışlardır (http://www.pwc.com.tr/tr/audit/sarbanes-oxley.jhtml). Ayrıca, finansal tabloları denetleyen kuruluşun yönetimin yaptığı değerlendirme ile ilgili bir "görüş" beyan etmesi gerekmektedir (Attestation Report) (PWC, 2004: 9). almaktadir.

PCAOB'ninICFR denetimleriyle ilgili yaptığı bazı çalışmalar Tablo 2'de yer

Tablo 2: PCAOB'nin ICFR ile ilgili yaptığı çalışmalar ve yayınladığı standartlar

\begin{tabular}{|l|l|}
\hline Y1l & Gelişme \\
\hline 2004 & $\begin{array}{l}\text { 2 No.lu Denetim Standardı yayınlanmıştır. Finansal raporlama ile ilgili iç kontrollere } \\
\text { ilişkin ilk standarttır. }\end{array}$ \\
\hline 2006 & $\begin{array}{l}1 \text { Mayıs tarihinde Kurul } 2 \text { no.lu standardının uygulanması konusunda bildiri } \\
\text { yayınlamıştır. }\end{array}$ \\
\hline 2007 & $\begin{array}{l}5 \text { No.lu Denetim Standardı ve ilave açıklamaları yayınlanmıştır. Bu standart ICFR } \\
\text { denetimlerinin uygulanması üzerinde durmaktadır. }\end{array}$ \\
\hline 2008 & Kurulun ICFR denetimlerinde 5 No.lu Denetim Standardına geçişlerinin etkinliği \\
\hline
\end{tabular}




\begin{tabular}{|l|l|}
\hline & üzerinde durulmuştur. ICFR denetim bulguları genel bir rapor halinde özetlenmiştir. \\
\hline $2009-2010$ & $\begin{array}{l}\text { Kurul 5 No.lu Standardın uygulamalarııı kontrole devam etmiştir. Denetim ekibi denetçi } \\
\text { raporunda bazı eksikliklere rastladığında denetim firması ile bağlantı kurmaktadır. }\end{array}$ \\
\hline 2012 & $\begin{array}{l}\text { Aralık ayında Kurul, 2010-2011 yıllarında saptadıkları eksikliklerin önemi ve sayısı ile } \\
\text { ilgili bir rapor yayınlamıştır. }\end{array}$ \\
\hline
\end{tabular}

Kaynak: PCAOBUS

ICFR denetimi mutlaka finansal tablo denetimiyle eş zamanlı olarak gerçekleştirilmelidir. Her ne kadar her iki denetimin amaçları aynı olmasa da, denetçi her iki denetimin amaçlarını gerçekleştirmesini sağlayacak bir plan takip etmelidir. ICFR ve finansal tabloların entegre edilmiş bir denetiminde denetçi, her ikisi için de denetimin amacını eş zamanlı olarak gerçekleştirebilmek için kendi kontrollerini tasarlamalıdır. Denetçi, yıl sonu itibariyle ICFR'ye ilişkin görüşlerini destekleyecek yeterli kanıtları elde etmeli ve finansal tabloların denetiminde kontrol risk değerlendirmelerini destekleyecek kanıtlar edinmelidir (Auding Standard No:5, 2007: 5-6).

ICFR'nin denetimini yapacak olan denetçinin amac1, ICFR'nin etkinliği üzerinde görüş sunmaktır. Çünkü etkin bir ICFR finansal tabloların güvenilirliği hususunda "makul bir güvence" sağlar. Eğer raporda bir veya daha fazla önemli zayıflık (material weaknesses) varsa raporun etkinliği son bulmaktadır (Uzay, Gönen, 2012: 46; Auditing Standart No:5, 2007: 4).

\section{SONUÇ}

Son yıllarda dünyada yaşanan skandallar dikkatleri denetim ve iç kontrol konularına çekmiştir. Güvenilir finansal raporlamanın gerçekleşebilmesi, iç kontrolün doğru işlemesine bağlıdır. İşletmelerde iç kontrol sistemlerinin oluşturulması ve etkin kullanılması için uluslararası boyutta kuruluşlar bazı iç kontrol çerçeveleri yayınlamaktadır. Bu çerçevelerin en yaygın olarak kullanılanları COSO tarafından yayınlanan çerçevelerdir.

Yaşanan skandalların ardından 2002 yılında yürürlüğe giren Sarbanes Oxley Kanunu piyasalarda kaybolan güven ortamının yeniden temin edilmesini amaçlamaktadır. $\mathrm{Bu}$ kapsamda Kanunla, Amerikan Sermaye Piyasası'nın (SEC) şirketlerinden düzenli ve zorunlu olarak Finansal Raporlama ile İlgili İç Kontrol Raporu istemeye başlamıştır. İç kontrolün daha geniş kapsamlı bir parçası olarak görülen bu rapor, özellikle finansal raporlamaya ilişkin riskleri gidermek amaciyla tasarlanmış kontrollerdir. SOA'ya göre Amerikan Sermaye Piyasası Kurulu, şirket üst yönetimlerinin yıllık iç kontrol değerlendirmelerini yaparken yani Finansal Raporlama ile ilgili İç Kontrol Raporunu (ICFR) hazırlarken, COSO iç kontrol çerçevelerinden yararlanabileceğini belirtmiştir (Uzay ve Gönen, 2012: 49). Böylece iç kontrolün öneminin arttırılması amaçlanmaktadır.SEC ve PCAOB yöneticileri 2013 ve 2014 yıllarında verdikleri demeçlerde ICFR'ye olan ilginin artması gerektiğini vurgulamışlardır.

Uzay ve Gönen (2012) çalışmalarında 6102 sayılı Türk Ticaret Kanunuile getirilen ve denetçiden düzenlenmesi istenen yıllık faaliyet raporunun denetiminin ICFR raporlaması ve denetimi ile benzerlik taşıdığını belirtmişlerdir. Türkiye'de de ilerleyen dönemlerde ICFR'nin SPK tarafından zorunlu hale gelmesi finansal raporlamanın güvenilirliğini arttıracaktır. 


\section{KAYNAKÇA}

Auditing Standard No:5, "An Audit of Internal Control Over Financial ReportingThat is IntegratedWith An Audit of Financial Statements", PublicCompany Accounting Oversight, 2007.

AYKAÇ, Özlem (2005), “AB Uyum Sürecinde İç Denetimin Değişen Dünyası ve Sigorta Sektöründe Yeni Düzenlemeler”, Avrupa Birliği'ne Uyum Sürecinde Türk Sigorta Sektörü - I. Ulusal Sigorta Sempozyumu, Mayıs 2005, 453-475.

COSO (2004), "Enterprise Risk Management-Integrated Framework Executive Summary", September 2004.

COSO (2013), "Internal Control- Integrated Framework Executive Summary”, May 2013.

Guide to Internal Control Over Financial Reporting (2013), http://www.thecaq.org/docs/reports-and-publications/caq_icfr_042513.pdf?sfvrsn=2

Erişim Tarihi: 22.06.2015.

INTOSAI GOV 9100 (2004), "Guidelines for Internal Control Standards for the Public Sector", http://www.issai.org/media/13329/intosai_gov 9100_e.pdf Erişim Tarihi: 01.08.2015.

KORKMAZ, Umut (2007), “Kamuda İç Denetim”, Bütçe Dünyası Dergisi, Sayı: 25(2), 4-15.

MCNALLY, J.S. (2013), "The 2013 Coso Framework\&SOX Compliance, One Approach to An Effective Transition", Strategic Finance, June 2013, 1-8.

MOELLER, Robert R. (2005), “Brink’s Modern Internal Auditing”, John Wiley\&Sons,Ltd.

PICKETT, K.H. Spencer (2003), “The Internal Auditing Handbook”, John Wiley\&Sons,Ltd.

PWC Price Waterhouse Coopers (2004), Genel Hatlarıyla Sarbanes Oxley Kanunu ve Türkiye'de Faaliyet Gösteren Şirketlere Etkisi, http://www.pwc.com.tr/tr TR/tr/assets/about/events/training/sarbox.pdf Erişim Tarihi: 20.06.2015.

The Updated COSO Internal Control Framework (2013) Protiviti, http://www.protiviti.com/en-US/Documents/Resource-Guides/Updated-COSOInternal-Control-Framework-FAQs-Second-Edition-Protiviti.pdf Erişim Tarihi: 01.07.2015.

TÜMER, Sumru (2010), “Kamuda İç Kontrol Sistemi ve Uygulama Aşamaları”, Güncel Mevzuatı Araştırma Ve Eğitim Derneği Yayınları, Ankara.

UZAY, Şaban ve Seçkin Gönen (2012), "Yeni TTK ile Getirilen Yıllık Faaliyet Raporu Denetiminin Finansal Raporlama ile İlgili İç Kontrol Raporu Denetimi ile Benzerlikleri”, Muhasebe Bilim Dünyası Dergisi, Cilt:14, Sayı 4, 43-63.

YILANCI, Münevver (2006), “İç Denetim: Türkiye'nin 500 Büyük Sanayi İşletme Üzerine Bir Araştırma”, Nobel Yayınevi, Ankara.

http://www.kgk.gov.tr/contents/files/BDS/BDS 200.pdf BDS 200 Erişim Tarihi: 20.05.2015

http://pcaobus.org/News/Speech/Pages/03262014 IIA.aspx Erişim Tarihi:18.05.2015

http://www.coso.org/documents/COSO\%20ICIF\%2011x17\%20cube\%20graphic.pdf Erişim Tarihi: 20.05.2015

http://www.coso.org/aboutus.htm Erişim Tarihi: 01.07.2015. 